Magyar Gyógyszerésztudományi Társaság Gyógynövény Szakosztály

\title{
XV. Magyar Gyógynövény Konferencia
}
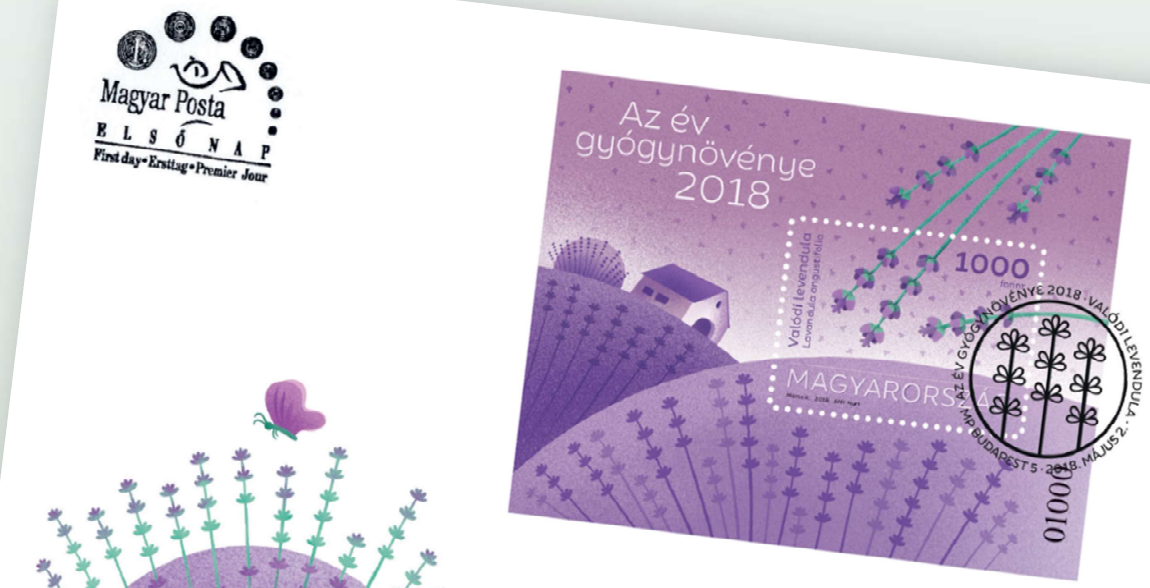

Visegrád 2018. június 8-9. 


\section{A XV. MAGYAR GYÓGYNÖVÉNY KONFERENCIA TÁMOGATÓI}

Fö támogató:

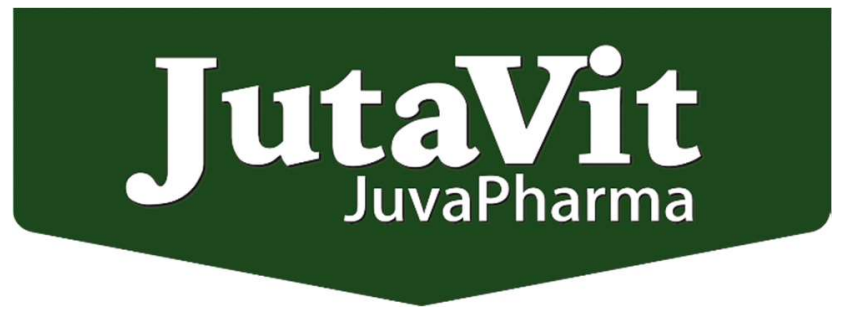

Aranyfokozatú támogatók:
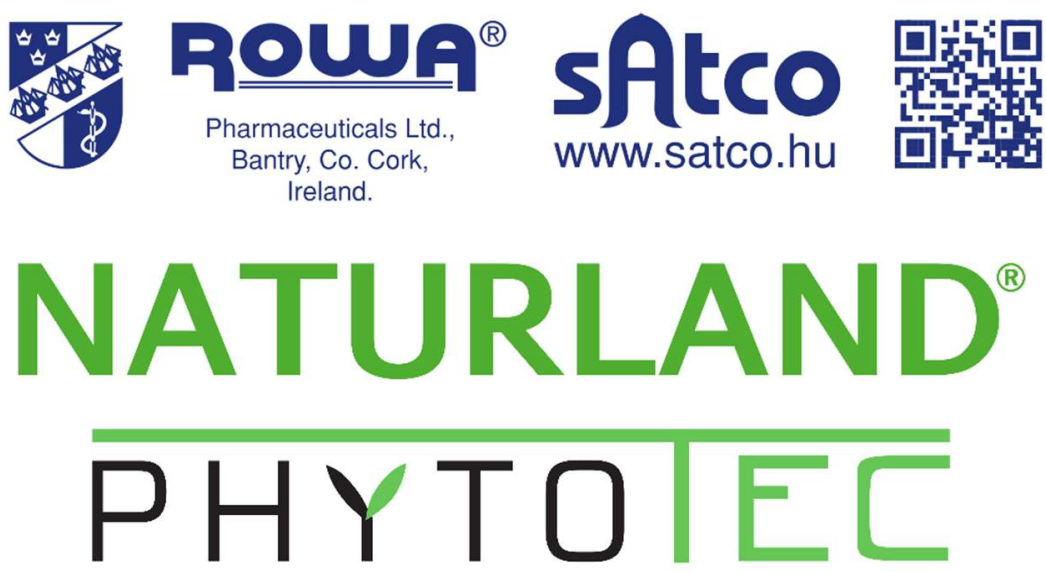

VALÓDI GYÓGYSZER A TERMÉSZETTŐL
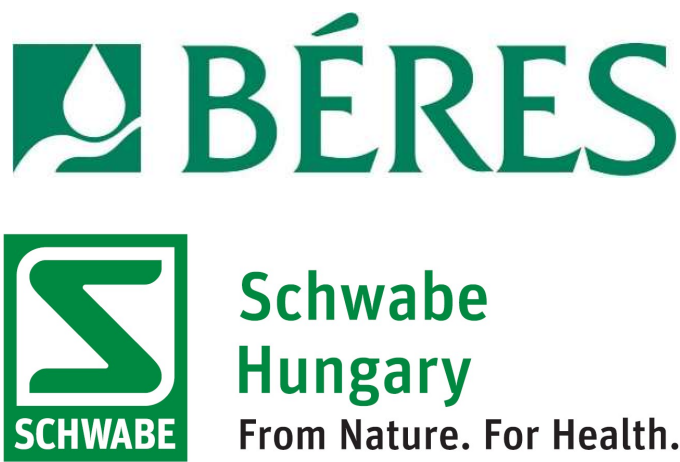

Schwabe

Hungary

From Nature. For Health. 


\title{
XV. Magyar Gyógynövény Konferencia
}

\author{
A Magyar Gyógyszerésztudományi Társaság \\ Gyógynövény Szakosztályának tudományos konferenciája
}

Visegrád, Hotel Visegrád

2018. június 8-9.

doi: 10.14232/mgyk.2018.af

A borítón a Magyar Posta Zrt. által kibocsátott, Az év gyógynövénye 2018: Valódi levendula c. bélyegblokk elsőnapi borítékának képe látható.

Tervező: Maros Krisztina. További információ: www.posta.hu

Kiadja a Magyar Gyógyszerésztudományi Társaság

Gyógynövény Szakosztálya

Szerkesztők: Kiss Tivadar, Rédei Dóra, Csupor Dezső

Szeged, 2018 



\section{PROGRAM}

2018. június 8. (péntek)

9:00-11:00

RENDEZVÉNYPOSTA - Bélyegvásárlási lehetőség Év gyógynövénye - Valódi levendula bélyegblokk

9:30 REGISZTRÁCIÓ

$10: 00$ MEGNYITÓ

\section{ELŐADÁSOK}

$10: 15-11: 55$

\section{SZEKCIÓ}

\section{ELNÖK: DELI JÓZSEF}

A1 - 10:15-10:40 Horváth Györgyi, Ács Kamilla, Balázs Viktória Lilla, Csikós Eszter, Ashraf Amir Reza, Kocsis Béla, Böszörményi Andrea, Horváth Barbara, Széchenyi Aleksandar, Kereskai László, Csekő Kata, Kemény Ágnes, Helyes Zsuzsanna:

A fahéjkéreg-illóolaj alkalmazhatósága légúti betegségek esetén - pécsi tapasztalatok

A2 - 10:40-11:05 Horányi Tamás:

A tudomány és a szabályozás „konfliktusa”: a gyógynövénytermékek helyzete Magyarországon

A3 - 11:05-11:30 Vasas Andrea, Bús Csaba, Stefkó Dóra, Kúsz Norbert, Tóth Barbara, Hohmann Judit:

Juncaceae fajok, mint ígéretes fenantrénforrások

A4 - 11:30-11:55 Vasas Gábor, Deli József, Riba Milán, Ujvárosi Andrea, Hanyicska Martin, Gonda Sándor, Kapás Kitti:

Karotinoid- és peptidmintázatok elemzése mikroalgákból 


\section{ELŐADÁSOK}

13:00-14:30 II. SZEKCIÓ

ELNÖK: VASAS GÁBOR

B1 - 13:30-13:25 Tóth Barbara, Lantos Tamás, Hegyi Péter, Viola Réka, Csupor Dezső:

A gyömbér posztoperatív hányinger- és hányáscsillapító hatásának metaanalízise

B2 - 13:25-13:50 Pluhár Zsuzsanna Szabó Dóra, Katarzyna Seidler-Lozykowska, Tavaszi-Sárosi Szilvia Détár Enikő, Zámboriné Németh Éva:

A kerti kakukkfü (Thymus vulgaris L.) fajták illóolaj-jellemzőit befolyásoló tényezők értékelése

B3 - 13:50-14:10 Bérci István:

Gyógynövénykészítmények kockázatértékelése a „Biztonságos étrend-kiegészítő program" keretében

B4 - 14:10-14:30 Román Gergely, Kursinszki László:

Eger környéki borok antocianin-összetételének tömegspektrometriás vizsgálata

\section{ELŐADÁSOK}

15:00-16:50 III. SZEKCIÓ

ELNÖK: ZÁMBORINÉ NÉMETH ÉVA

C1 - 15:00-15:25 Szendrei Kálmán, Tóth Barbara, Csupor Dezső:

Szakmapolitika, de miért és hogyan?

C2 - 15:25-15:50 Hohmann Judit:

$A z$ „ötlet” a gyógynövénykutatás eszköztárában

C3 - 15:50-16:10 Bencsik Tímea, Kovács Kinga:

Kálmosgyökértörzs-teák 6 -azaron-tartalmának meghatározása és fogyasztásának felmérése napjainkban 
C4 - 16:10-16:30 Gosztola Beáta, Balogh Dóra, Ruttner Klára:

A betakarítási idő hatása a moldvai sárkányfü (Dracocephalum moldavica L.) droghozamára és minőségére

C5 - 16:30-16:50 Ruscsák Erika:

NATURLAND evolution

$18: 00$ KOCCINTÁS A KIRÁLYI PALOTÁBAN

$18: 30$

KIRÁLYI LAKOMA ÉS BARÁTI BESZÉLGETÉS A RENAISSANCE ÉTTEREMBEN

2018. június 9. (szombat)

\section{ELŐADÁSOK}

9:00-10:25 IV. SZEKCIÓ

ELNÖK: HOHMANN JUDIT

D1 - 9:00-9:25 Nagy Zsolt:

Egy Kárpát-medencei drogadatbázis szerkesztésének tanulságai és használatának lehetőségei - Farmakobotanikai térképezés a Kis-Küküllő és Nyárád folyók mentén

D2 - 9:25-9:45 Lopes-Szabó Zsuzsanna:

György füvesember és a Györgytea története

D3 - 9:45-10:05 Papp Nóra:

Etnofarmakobotanikai monográfiák a Homoródok mentéről (Erdély) - Könyvbemutató

D4 - 10:05-10:25 László-Bencsik Ábel, Szatmáry Miklós:

Ellenségből barát - vagy jogos-e a xenofóbia?

10:25-10:55

KÁVÉSZÜNET 
10:55-11:20 V. SZEKCIÓ

ELNÖK: BÉNI SZABOLCS, CSUPOR DEZSŐ

E1 - 10:55-11:20 Hunyadi Attila:

A kémiai tér bővítése: természetes és félszintetikus ekdiszteroidokkal rezisztens tumorok ellen

E2 - 11:20-11:40 Böszörményi Andrea, Dobi Adrienn, Pávai Melinda, Solymosi Katalin:

A fény hatása a rozmaring illóolajtermelésére

E3 - 11:40-12:00 Biróné Sándor Zsuzsanna:

Az Európai Gyógyszerügynökség Gyógynövény Bizottságának elmúlt 3 évi tevékenysége

E4 - 12:00-12:20 Patonay Katalin, Szabó-Hudák Orsolya, Szalontai Helga, Pénzesné Kónya Erika, Zámboriné Németh Éva:

Lómenta (Mentha longifolia (L.) L.) mint lehetséges antioxidáns-forrás felmérése észak-magyarországi mintákon

E5 - 12:20-12:40 Polgár Tímea, Lapusnyik Nóra, Horváth Péter: GLOBE Program Association: Kollaboratív és innovatív tudásplatform a természetes hatóanyagok $\mathrm{K}+\mathrm{F}$ támogatásához

$12: 40-14: 00$

EBÉDSZÜNET

14:00-15:00 MGYT Gyógynövény Szakosztály vezetőségi ülése 


\section{ELŐADÁSKIVONATOK}




\section{A fahéjkéreg-illóolaj alkalmazhatósága légúti betegségek esetén - pécsi tapasztalatok}

Horváth Györgyi ${ }^{1, *}$, Ács Kamilla ${ }^{1}$, Balázs Viktória Lilla ${ }^{1}$, Csikós Eszter ${ }^{1}$, Ashraf Amir Reza $^{1}$, Kocsis Béla ${ }^{2}$, Böszörményi Andrea ${ }^{3}$, Horváth Barbara ${ }^{4}$, Széchenyi Aleksandar ${ }^{4}$, Kereskai Lászlón, Csekö Kata $^{6}$, Kemény Ágnes $^{6}$, Helyes Zsuzsanna ${ }^{6,7}$

1 PTE GYTK Farmakognóziai Intézet, 7624 Pécs, Rókus u. 2.

2 PTE ÁOK Orvosi Mikrobiológiai és Immunitástani Intézet, 7624 Pécs, Szigeti út 12.

${ }^{3}$ SE GYTK Farmakognóziai Intézet, 1085 Budapest, Üllői út 26.

${ }^{4}$ PTE GYTK Gyógyszertechnológiai és Biofarmáciai Intézet, 7624 Pécs, Rókus u. 2.

${ }^{5}$ PTE ÁOK Pathologiai Intézet, 7624 Pécs, Szigeti út 12.

${ }^{6}$ PTE ÁOK Farmakológiai és Farmakoterápiai Intézet, 7624 Pécs, Szigeti út 12.

${ }^{7}$ PTE Szentágothai János Kutatóközpont, 7624 Pécs, Ifjúság útja 20.

*e-mail: horvath.gyorgyi@gytk.pte.hu

A WHO 2015-ös felmérése alapján az alsó légúti megbetegedések a 10 vezető halálok listáján a harmadik helyet foglalják el. Mivel az antibiotikum-rezisztencia egyre nagyobb problémát jelent az egészségügyben, igény mutatkozik a kiegészítő terápiák iránt. Az illóolajokat inhalálással már régóta használják légúti betegségek kezelésében. Azonban a növényi eredetű kivonatokkal kapcsolatban is elvárás, hogy hatásosságuk több tesztrendszerben is bizonyítva legyen. Ezért munkánk során célul tűztük ki a fahéjkéreg-illóolaj antibakteriális és gyulladáscsökkentő hatásának tanulmányozását in vitro és in vivo modellekben.

A fahéjkéreg-illóolaj kémiai összetételét GC-FID/MS és SPME-GC-MS módszerekkel határoztuk meg. Az illóolaj antibakteriális hatását csőhígítás és gőzteres módszerekkel teszteltük légúti kórokozók ellen. A biofilmgátló hatást az illóolaj nanotechnológiai eljárással készült emulziójával végeztük. A gyulladásgátló hatást LPSindukált akut légúti gyulladás egérmodelljében tanulmányoztuk.

Az illóolaj fő komponense a transz-fahéjaldehid $(74,0 \%, 46,0 \%)$ volt mindkét analitikai rendszerben. Folyékony táptalajban a fahéjkéregolaj antibakteriális hatást mutatott a Streptococcus pyogenes, S. pneumoniae, S. mutans és Haemophilus influenzae, $H$. parainfluenzae ellen (MIC: $0,06 \mathrm{mg} / \mathrm{ml}$ ). A gőzteres vizsgálatban az illóolaj a Haemophilus törzsek ellen volt a leghatásosabb (MIC: 15,6 $\mu \mathrm{L} / \mathrm{L}$ ). A S. mutans biofilm-képzését a fahéjkéregolaj nanotechnológiai eljárással készült emulziója hatékonyabban csökkentette a Tween 80 és alkohollal készült mintákhoz képest. Az állatmodellben a fahéjkéregolaj inhalációja csökkentette a légúti hiperreaktivitást, szövettani képeken a makrofág-akkumulációt, viszont az MPO-aktivitást nem befolyásolta. 


\section{A tudomány és a szabályozás „konfliktusa”: a gyógynövénytermékek helyzete Magyarországon}

\section{Horányi Tamás}

Béres Gyógyszergyár Zrt. , 1037 Budapest Mikoviny utca 2-4.

e-mail: horanyi.tamas@beres.hu

Vannak, akik értenek a gyógynövényekhez (talán ők vannak manapság kevesebben) és vannak nagyszámban olyanok, akik az üzleti lehetőséget látják az ezekből készült termékekben.

Vajon mi értelme az olyan gyógynövénykészítményeknek, melyek összetételüknél és hatáserősségüknél fogva bizonyosan nem rendelkeznek gyógyhatással? - tehetjük fel magunknak a kérdést, ha a tudományos oldalról közelítünk a témához. Másrészt, milyen jelentősége van azoknak a gyógynövényeknek, melyek hatásosságában szakmai konszenzus mutatkozik, de gyógyszerként belátható időn belül aligha juthatnak el a fogyasztókhoz? A szabályozási rendszerek sajátossága ugyanis nem teszik lehetővé, hogy terápiás célra szánt készítmény alkotórészei legyenek.

Tudjuk, ezek nem új keletű felvetések és aligha adható kielégítő válasz ezekre a kérdésekre. Az előadás nem is arra vállalkozik, hogy megoldja a tudomány és a szabályozás ezen régóta fennálló konfliktusát, hanem arra, hogy képet adjon a gyógynövénykészítmények hazai helyzetéről, a lehetőségekről és korlátokról. 


\section{Juncaceae fajok, mint ígéretes fenantrénforrások}

Vasas Andrea* ${ }^{*}$, Bús Csaba, Stefkó Dóra, Kúsz Norbert, Tóth Barbara, Hohmann Judit SZTE GYTK Farmakognóziai Intézet, 6720 Szeged, Eötvös u. 6.

\section{*e-mail: vasasa@pharmacognosy.hu}

A Juncaceae család közel 500 faját hét nemzetségbe sorolják, amelyek közül a két legnagyobb a Juncus és a Luzula. Irodalmi adatok alapján a fajok fő bioaktív komponensei a flavonoidok és a fenantrének. Noha a fenantréntartalmú növényeket a népi gyógyászatban számos betegség kezelésére alkalmazzák, kémiai összetételük és hatásmechanizmusuk kevéssé vizsgált. Munkánkat megelőzően közel száz fenantrént izoláltak a Juncus nemzetség öt fajából. A vegyületek érdekes biológiai hatásaik (pl. antitumor, antibakteriális, gyulladáscsökkentő, antioxidáns, nyugtató, görcsoldó) és szerkezeti változatosságuk miatt nagy érdeklődésre tartanak számot.

Munkánk célja a Kárpát-medencében előforduló Juncaceae fajok fitokémiai és farmakológiai vizsgálata volt. Előkísérleteink során 19 faj antibakteriális, gyulladáscsökkentő és antiproliferatív hatásának szűrővizsgálatát végeztük el. Metanolos extrakciót követően folyadék-folyadék megosztással különböző polaritású frakciókat állítottunk elő, amelyeknek teszteltük farmakológiai hatásait. Elsősorban a diklórmetános és az etil-acetátos frakciók bizonyultak aktívnak. Az elővizsgálatok alapján a Juncus inflexust, J. compressust, J. atratust, J. gerardiit és a Luzula luzuloidest választottuk ki további fitokémiai és farmakológiai vizsgálatok céljára. A vegyületek izolálása különböző kromatográfiás módszerek (oszlop, preparatív vékonyréteg, gélszűrés és HPLC) kombinálásával történt. A szerkezetmeghatározást spektroszkópiai módszerekkel (1D és 2D NMR, HRMS) végeztük. Néhány esetben az abszolút konfiguráció meghatározására is sor került.

Eddig 47 fenantrént, köztük 17 új anyagot azonosítottunk a vizsgált fajokból. A vegyületek metil-, hidroxi-, metoxi-, oximetilén-, hidroxietil- és vinilcsoportokkal szubsztituáltak. A Juncus fajokból izolált fenantrének nagy része vinilcsoportot tartalmaz, így ezek a vegyületek kemotaxonómiai markerekként is szolgálhatnak.

Néhány izolált anyag jelentős antibakteriális hatással rendelkezik methicillinrezisztens Staphylococcus aureus ellen. Ezen vegyületek jelenlétét a leghatásosabb kivonatokban LC-MS vizsgálattal mutattuk ki. Az in vitro antiproliferatív vizsgálat során a junkuzol mutatott szelektív citotoxikus hatást HeLa sejteken; növelte a sejtpopulációt a G2/M és a szub-G1 fázisban, valamint gátolta a tubulin polimerizációt. A L. luzuloidesből izolált vegyületek gátolták az fMLP/CB által indukált szuperoxid anion termelődését és az elasztáz-felszabadulást humán neutrofilekben. Néhány fenantrén anti-HSV-2 aktivitással rendelkezik. 


\section{Karotinoid- és peptidmintázatok elemzése mikroalgákból}

Vasas Gábor ${ }^{1, *}$, Deli József², Riba Milán ${ }^{1}$, Ujvárosi Andrea $^{1}$, Hanyicska Martin ${ }^{1}$, Gonda Sándor ${ }^{1}$, Kapás Kitti ${ }^{1}$

${ }^{1}$ DE Növénytani Tanszék, 4032 Debrecen, Egyetem tér 1.

2 PTE GYTK Farmakognóziai Intézet, 7624 Pécs, Rókus u 2.

*e-mail: vasas.gabor@science.unideb.hu

A gyógyászatban felhasznált, étrend-kiegészítőként alkalmazott növényi eredetú készítmények, gyógyszerek manapság még több mint 90 \%-a a magasabb szerveződésű hajtásos növényekből származnak, ugyanakkor egyre nagyobb figyelem irányul a mikroalgák ilyen irányú alkalmazására. Részben tradicionális okokból, részben napjaink klinikai, preklinikai vizsgálataira alapozva néhány algafaj terméke közvetlen felhasználásra kerül étrend-kiegészítőként, gyógyhatású készítményként. Az elmúlt időszakban, párhuzamosan a szerkezetazonosító módszerek fejlődésével, ezen élőlénycsoportból számos különleges metabolit, különböző biológiai aktivitással került leírásra.

A növényvilág talán legszembetűnőbb, szemet gyönyörködtetőbb molekulái azok a karotinoid színanyagok amelyek, részben fotoszintézisük hatékonysága érdekében, részben védekezés vagy egyéb funkciók érdekében termelnek a növények, így az algák is. Egyes mikroalgák, cianobaktériumok pedig lineáris és ciklikus peptidtermelése jelentős aktivitást mutat, amelyek közül elsősorban egyes proteázgátlók számítanak jelentős érdeklődésre.

Előadásunkban, a kutatócsoportunk elmúlt éveinek alapkutatási eredményeit foglaljuk össze e témakörben, amelyben a karotinoidok és az erős biológiai aktivitással bíró peptidek, glikopeptidek azonosítását, sajátosságainak elemzését végeztük mikroalgákból. Előadásunkban tárgyaljuk:

- A Dunaliella sp. mikroalga karotinoidtermelésének sajátosságait

- A Haematococcus pluvialis astaxantin termelésének és azonosításának eredményeit

- Egy vízoldékony karotinoid-glikozid azonosítását mikroalgából

- Peptidmintázatok elemzését és biológiai aktivitását cianobaktériumokból 


\section{A gyömbér posztoperatív hányinger- és hányáscsillapító hatásának metaanalízise}

Tóth Barbara $^{1, *}$, Lantos Tamás ${ }^{2}$, Hegyi Péter ${ }^{3}$, Viola Réka ${ }^{4}$, Csupor Dezsö $^{1}$

${ }^{1}$ SZTE Farmakognóziai Intézet, 6720 Szeged, Eötvös utca 6.

${ }^{2}$ SZTE Orvosi Fizikai és Orvosi Informatikai Intézet, 6720 Szeged, Rerrich Béla tér 1.

${ }^{3}$ PTE Transzlációs Medicina Intézet, 7624 Pécs, Szigeti út 12.

${ }^{4}$ SZTE Klinikai Gyógyszerészeti Intézet, 6725 Szeged, Szikra utca 8.

*e-mail: toth.barbara@pharmacognosy.hu

A posztoperatív hányinger és hányás gyakori velejárója az általános anesztéziában végzett mútéteknek, és további, súlyos komplikációkhoz (pl. aspirációs tüdőgyulladás, mútéti seb felszakadása, nyelőcsőrepedés, dehidratáció) vezethet. A gyömbért (Zingiber officinale) az emberiség évezredek óta alkalmazza gyógy- és füszernövényként többek között hányinger- és hányáscsillapítás céljából is. A közelmúltban számos humán vizsgálatot végeztek a gyömbér hányinger- és hányáscsillapító hatásának igazolására.

Munkánk célja a gyömbér posztoperatív hányinger- és hányáscsillapító hatásának értékelése a rendelkezésre álló placebókontrollos, randomizált, kettős vak klinikai vizsgálatok metaanalízisével.

A metaanalízist előzetes PROSPERO regisztrációt követően a PRISMA irányelvek alapján készítettük el. Az irodalomkutatást az Embase, a Web of Science, a PubMed és a Cochrane Central Register of Controlled Trials adatbázisok segítségével végeztük. A kvantitatív analízis során azokat a humán klinikai vizsgálatokat vettük figyelembe, amelyekben terápiás dózisú gyömbért per os alkalmaztak mútött betegeken.

A végső statisztikai analízishez tíz klinikai vizsgálatot választottunk ki. A vizsgálatok metaanalízise alapján a gyömbér csökkenti a posztoperatív hányás incidenciáját. Ezen kívül a vizuális analóg skála eredményei alapján a placebóhoz képest a gyömbér szignifikánsan mérsékeli a posztoperatív hányinger és hányás súlyosságát. A posztoperatív hányinger incidenciájára, valamint a sürgősségi hányáscsillapítók alkalmazásának igényére a gyömbér nem volt statisztikailag szignifikáns hatással.

Az általunk elvégzett metaanalízis alapján a gyömbér biztonságos és jól tolerálható alternatív megoldás lehet a mútétet követő hányás előfordulásának csökkentésére. 


\section{A kerti kakukkfü (Thymus vulgaris L.) fajták illóolaj-jellemzőit befolyásoló tényezők értékelése}

Pluhár Zsuzsanna ${ }^{1, *}$ Szabó Dóra ${ }^{1}$, Katarzyna Seidler-Lozykowska², Tavaszi-Sárosi Szilvia ${ }^{1}$ Détár Enikö ${ }^{1}$, Zámboriné Németh Éva ${ }^{1}$

${ }^{1}$ Szent István Egyetem, Kertészettudományi kar, Gyógy-és Aromanövények Tanszék, Budapest

${ }^{2}$ Institute of Natural Fibres and Medicinal Plants, Poznan, Lengyelország

*e-mail: pluhar.zsuzsanna@kertk.szie.hu

A Thymus vulgaris illóolajának variabilitása jól ismert, melyet széleskörű kutatások eredményei támasztanak alá. Az egyes fajták produktivitása a különböző termesztő körzetekben azonban kevéssé feltárt. Ezirányú kísérleteink keretében párhuzamos szabadföldi kísérletek beállítására került sor 2014-2016 között Budapesten és a lengyelországi Poznanban, négy timol kemotípusba tartozó kerti kakukkfü fajta bevonásával: 'Varico 3' (V3), 'Sloneczko' (SL), 'Standard Winter' (SW) és 'French Summer' (FS). A három éven keresztül folyó vizsgálatok során értékeltük a termőhelyek (Budapest, Poznan), az évjáratok (2014, 2015, 2016), a növények fejlődési fázisainak (vegetatív, bimbós, virágzó, elvirágzott) és az állományok életkorának (1,2,3 éves) hatását az egyes fajták illóolaj-termelő képességére, valamint illóolajuk minőségére vonatkozóan.

Megállapítottuk, hogy jelentős különbségek mutathatók ki a fajták illóolajtermelő képessége és az illóolaj minősége tekintetében, melyet a termőhely, a növények életkora és az ontogenetikai fázisok egyaránt befolyásolnak. A fajták közül a 'Varico 3' kiemelkedő illóolaj-termelő képességgel rendelkezett, különösen az első évben (Poznan: 5,78 ml/100 g; Budapest: 3,97 ml/100 g). Az életkor előrehaladtával szignifikáns csökkenés következett be minden fajta illóolaj-tartalmában, mindkét termőhelyen (pl. Budapesten: 2014 (1. év): 2,78 ml/100 g; 2015 (2. év): 1,59 ml/100 g; 2016 (3. év): 1,09 ml/100 g). A termőhelyek közül Budapest összességében előnyösebbnek bizonyult minden fajta számára, ha a teljes életciklust vizsgáljuk, de az egyes évek és a fajták átlagát tekintve is (pl. 2016-ban: Poznan: 0,846 ml/100 g; Budapest 1,099 ml/100 g). A timol komponens illóolajban kimutatható aránya minden esetben a gyógyszerkönyvi előírásoknak $(40 \%<)$ megfelelő volt, de legmagasabb értékei a teljes virágzásban voltak mérhetők $(71,09 \%)$, melyet a vegetatív fázis követett (67,09\%), két év $(2015,2016)$ és a fajták átlagában. A fajták között azonban jelentősebb eltérések voltak kimutathatók a timol \%-os alakulásában (V3: 75,44\% $\rightarrow$ FS: $67,08 \%)$ és annak tendenciáiban egy (V3, SW) vagy két (FS, SL) maximum értékkel az 
adott tenyészidőszakon belül. E fajtatulajdonságok mérlegelendők a termesztés során, az állományok korának előrehaladtával, különösen a harmadik évtől.

\section{Köszönetnyilvánítás:}

Köszönjük az NKFIH-OTKA támogatását a nemzetközi együttmúködésben, NN108633 sz. alatt végzett kutató munkánkhoz. 


\section{Gyógynövény készítmények kockázatértékelése a „Biztonságos étrend-kiegészítő program" keretében}

\section{Bérci lstván}

Magyarországi Étrend-kiegészítő Gyártók és Forgalmazók Egyesülete, 2921 Komárom, Kőolaj u. 2.

e-mail:mekisz@mekisz.hu

Az elmúlt hónapokban számos fórumon előkerült a „Biztonságos étrend-kiegészítő program”, amelynek sikeres múködéséhez nem csupán a létrehozói (a Magyar Gyógyszerészi Kamara, a Gyógyszer-nagykereskedők Szövetsége, a Magyarországi Gyógyszergyártók Országos Szövetsége, a Hamisítás Elleni Nemzeti Testület és a Magyar Étrend-kiegészítő Gyártók és Forgalmazók Egyesülete), hanem minden piaci szereplő: gyártók, forgalmazók, gyógyszerészek, hatóságok, fogyasztók is nagy reményeket füznek. Közös elkötelezettség egy olyan rendszer létrehozása, amely a hatósági folyamatokat támogatva segíteni tudja a nem megfelelő minőségú termékek piacra jutásának megakadályozását. Ez különösen igaz a notifikációs rendszer tavaly novemberi átalakulása óta, mely formális folyamattá tette a bejelentések tudomásulvételéről szóló OGYÉl határozatok kiadását.

Napjainkban a kockázatértékeléseknek jól elfogadott gyakorlata van, de a megfelelő eljárás kiválasztása során meg kell találni az egyensúlyt a kellő szigorúság és a rendszer működőképességét biztosító racionalistás között. Az előadásban beszámolunk a „Biztonságos étrend-kiegészítő program” keretében folyó kockázatértékelésről, az abban rejlő lehetőségekről, de szembenézünk a rendszer korlátaival is. 


\section{Eger környéki borok antocianin összetételének tömegspektrometriás vizsgálata}

\section{Román Gergely, Kursinszki László*}

Semmelweis Egyetem, Farmakognóziai Intézet, 1085 Budapest, Üllői út 26.

*e-mail: kursinszki.laszlo@pharma.semmelweis-univ.hu

Az antocianinok a fenoloidok hatóanyag osztályába tartozó speciális anyagcseretermékek, melyek felelősek a kék szőlők és a vörös borok színéért. Jelentős szerepet játszanak a borok érési és öregedési folyamatai során, továbbá fajtaeredetük meghatározásában. Mérsékelt borfogyasztás esetén jelentős egészségvédő hatásuk is lehet. Jelen előadás Eger környéki borok antocián-összetételének vizsgálatával kapcsolatos eredményekről számol be.

Munkánk során egy családi pincészetből származó, különböző évjáratú Pinot Noir (2017, 2016, 2015), Merlot (2017, 2016), és Kadarka (2017, 2016) borok antocianin spektrumát vizsgáltuk. A minták analíziséhez egy nagyhatékonyságú folyadékkromatográfiás készülékkel kapcsolt, elektroporlasztásos ionforrással szerelt, hármas kvadrupól tandem tömegspektrométert használtunk, pozitív ionizációs üzemmódban. A HPLC elválasztásokat Zorbax SB-C18 Solvent Saver plus $(3,5 \mu \mathrm{m})$ fordított fázisú oszlopon (150x3,0 mm i.d.) végeztük, lineáris gradiens elúcióval, 2\%-os (v/v\%) vizes hangyasav és $2 \%(\mathrm{v} / \mathrm{v} \%)$ hangyasavat tartalmazó acetonitril oldószerek felhasználásával. Az antocianinok azonosítása során a kromatográfiás csúcsok retenciós idejét és tandem MS spektrumát hasonlítottuk össze autentikus standard megfelelő értékeivel, illetve az irodalomban közölt adatokkal. Az antocianinok mennyiségi LC-MS meghatározását peonidin-3-O- $\beta$-glükopiranozid autentikus standard felhasználásával, szelektált ionpásztázásos (SIM) üzemmódban végeztük.

$\mathrm{Az}$ eredményeket összegezve, a kvalitatív analízis során összesen 17 komponenst azonosítottunk, köztük antocianidin-monoglikozidokat és monoglikozid észtereket, valamint malvidinszármazék piranocianidineket. A vizsgált borfajták, és évjárataik összehasonlító elemzése során az antocianin-összetételben és -tartalomban egyaránt jelentős, a fajtaeredettel összhangban álló eltéréseket találtunk. 


\section{Szakmapolitika, de miért és hogyan?}

Szendrei Kálmán, Tóth Barbara, Csupor Dezsö*

Szegedi Tudományegyetem, Farmakognóziai Intézet, 6720 Szeged, Eötvös u. 6.

*e-mail: csupor.dezso@pharmacognosy.hu

Az utóbbi néhány évben a gyógynövényalkalmazás egyre szélesebb körűvé válását számos, tudatlanságból vagy merkantil szellem által vezérelt szakszerútlenség kíséri. Miután ez a jelenség csak egyike a társadalomban ma tömegesen jelenlévő hasonló tendenciáknak, fennáll annak a veszélye, hogy a rendcsinálás jogos igénye egy nagyobb kezdeményezés részeként olyan helyzetet teremthet, amelyben a közhangulatot és a szabályokat mélyebb szakmai ismeretek és megfontolások nélkül alakítják. Ennek első, sporadikus jelei már korábban is megjelentek éles vitákat generálva.

Annak érdekében, hogy a gyógynövényekkel kapcsolatos viták, szabályozási próbálkozások a szakmailag kívánatos módon folyjanak, proaktív magatartásra van szükség a gyógynövényekkel foglalkozó szakemberek részéről. A munka részesei tágabb körben a gyógyszerészek, akik a gyógynövényekkel kapcsolatos ismeretek közvetítői, az attitǔd formálói a lakosság felé. A tervezésben és koordinációban kiemelt szerep hárul az MGYT Gyógynövény Szakosztályra. Az előadás felvázolja magát a jelenséget, annak negatív aspektusait és bemutatja a cselekvés lehetőségeit. 


\section{Az „ötlet” a gyógynövénykutatás eszköztárában}

Hohmann Judit

Szegedi Tudományegyetem, Farmakognóziai Intézet, 6720 Szeged, Eötvös u. 6.

e-mail: hohmann@pharm.u-szeged.hu

Az igen szerteágazó gyógynövénykutatás sokféle megközelítést alkalmaz a kutatandó téma kiválasztásában, problémafelvetéseiben. A növényi hatóanyagok izolálása során leggyakrabban kémiai vagy farmakológiai szűrővizsgálatok eredményei vezetik a kutatót az ígéretes növényfajok kijelölésében, esetenként valamilyen természetes vezérmolekula hívja fel a figyelmet egy-egy növényfajra vagy nemzetségre. A népi gyógyászati megfigyelések ugyancsak gyakran szolgálnak kiindulópontként növénykémiai, farmakológiai munkákhoz. A növényanalitika területén valamely kivonat összetétel-vizsgálata vagy egyes termékek standardizálása iránti igényből indulnak ki a kísérletek, esetleg termékhamisítás igazolását vagy cáfolatát célozzák. A természetes anyagok félszintézisével általában hatás-szerkezet összefüggések elemzéséhez szükséges szerkezetileg analóg, új vegyületek vagy vegyületsorozatok előállítását végzik a kutatók.

A gyógynövénykutatás minden területén fontos szerepet játszik az "ötlet”. Hogy jó ötlete szülessen a kutatónak, mindenekelőtt alapos szakmai felkészültségre, széleskörü tájékozottságra, a módszerek és az eszköztár kiváló ismeretére, és nem utolsó sorban jó megfigyelőképességre van szükség. Az ezek alapján születő ötlet olyan kísérletek hajtóereje lehet, amelyek eredeti, új felismerésekhez vezetnek. Az ötlet persze egy hipotézis, feltételezés, amit igazolni kell, tehát valódi értékét a megvalósítás adja.

Jelen előadás olyan témákat kíván bemutatni a gyógynövénykutatás területéről, melyek mindegyikében fontos szerepet játszott valamilyen jó ötlet. Valamennyi téma elindítója és mozgatója a kutatói kreativitás és zsenialitás, amely minden esetben érdekes, új tudományos eredményhez vezetett. 


\section{Kálmosgyökértörzs-teák B-azaron-tartalmának meghatározása és fogyasztásának felmérése napjainkban}

\section{Bencsik Tímea*, Kovács Kinga}

PTE GYTK Farmakognóziai Intézet, 7624 Pécs, Rókus u. 2.

*e-mail: timea.bencsik@aok.pte.hu

A gyógyteák napjainkban növekvő népszerűségnek örvendenek. Még a klinikailag kevésbé vizsgált teáknak is jelentős szerepe lehet a gyógyászatban, hiszen egyes indikációkban hiánypótló szerepet tölthetnek be. A lehetőségek mellett azonban fontos felhívni a betegek figyelmét a gyógyteák fogyasztásával kapcsolatos veszélyekre is.

Gyógyszertárban dolgozó szakemberek kerestek meg bennünket egy esettel, amelynek során egy betegnél kálmosgyökértörzs-tea fogyasztását követően kellemetlen mellékhatás (szokatlanul erős menstruációs vérzés) jelentkezett. Ezért készítettünk egy kérdőívet, amellyel célunk volt felmérni, hogy kálmosgyökértörzsből készített tea fogyasztása során tapasztalt-e bárki más is hasonló vagy egyéb mellékhatásokat. Emellett négy különböző gyártótól (Herbária, Adamo, Naturland, JuvaPharma) származó kálmosgyökértörzs monoteát is vizsgáltunk: tartalmaznak-e 6-azaront, és ha igen, abból mennyi oldódik ki, ha vizes kivonatot (vagyis a csomagoláson feltüntetett javaslat szerint teát) készítünk.

A kérdőíves felmérésből kiderült, hogy Pécs és Szombathely környékén meglehetősen kevesen ismerik és alkalmazzák ezt a gyógynövényt. Az interjú kapcsán a kálmosnak tulajdonított mellékhatást sem a szakirodalmi adatok között, sem a kérdőíves felmérés során nem említette egy beteg sem, illetve a megkérdezett pécsi és szombathelyi fogyasztók semmilyen más panaszt nem tapasztaltak, sőt, nagy többségük tünetei (étvágytalanság, rossz emésztés, puffadás) megszűntek a gyógynövény fogyasztását követően.

A HPLC-mérések alapján a kálmosgyökértörzs monoteák mindegyike tartalmazott 6 -azaront, és mindegyik termék esetén elmondható, hogy ha a beteg a csomagoláson feltúntetett módon készíti el a teát, és mind a $200 \mathrm{ml}-\mathrm{t}$ el is fogyasztja, a 6 -azaron rossz vízoldékonysága ellenére még így is messzemenően (2-12-szeresen) túllépi a hatóságok által javasolt maximális $115 \mu$ g-os napi 6 -azaron-bevitelt.

Köszönetnyilvánítás: Köszönjük gyógyszertárban dolgozó kollégáink témafelvetését és az adatközlők hozzájárulását a kérdőíves felméréshez. Az analitikai mérések kivitelezéséhez anyagi támogatást a PTE ÁOK Posztdoktori Ösztöndíj program biztosított. 


\section{A betakarítási idő hatása a moldvai sárkányfü (Dracocephalum moldavica L.) droghozamára és minőségére}

\section{Gosztola Beáta* ${ }^{*}$ Balogh Dóra, Ruttner Klára}

Szent István Egyetem, Kertészettudományi Kar, Gyógy- és Aromanövények Tanszék, 1118 Budapest, Villányi út 29-43.

\footnotetext{
*e-mail: gosztola.beata@kertk.szie.hu
}

A moldvai sárkányfű régóta ismert és kedvelt egyéves gyógy- és füszernövényünk. Virágzó állapotban gyűjtött és megszárított föld feletti hajtása és illóolaja étvágyjavító, emésztést serkentő, szélhajtó, görcsoldó és nyugtató hatású, de kísérleti eredmények alapján antiszeptikus, antibakteriális és számottevő antioxidáns tulajdonságokkal is rendelkezik. A kínai gyógyászatban szív- és érrendszeri betegségek ellen alkalmazzák. Az élelmiszeriparban édes borok, ürmösök, üdítők, saláták ízesítője, de ízjavítóként teakeverékekbe is teszik.

Kísérletünkben a betakarítási idő droghozamra (morzsolt drogtömeg) és annak minőségére (illóolaj-tartalom és -összetétel, összfenol-tartalom, antioxidánskapacitás) gyakorolt hatását vizsgáltuk 8 eltérő származású moldvai sárkányfü taxon esetén. Az állományokat 2017-ben Soroksáron létesítettük azonos környezeti körülmények között, ahol a mintavételezésre 5 alkalommal: virágzás előtt, virágzás kezdetén, teljes virágzásban, elvirágzáskor és magérés stádiumában került sor.

A morzsolt drogtömeg virágzás előtt volt a legalacsonyabb minden taxon esetén (5,1-7,3 g/egyed), a legmagasabb pedig teljes virágzásban ill. elvirágzáskor (11,3-23,3 g/egyed), de a populációk között is mutatkoztak szignifikáns különbségek. Az illóolaj-tartalom a virágzás folyamán növekvő tendenciát mutatott, a taxonok többségénél teljes virágzáskor érte el maximumát $(0,56-1,04 \mathrm{ml} / 100 \mathrm{~g})$, majd elnyíláskor jelentősen lecsökkent mennyisége. A legalacsonyabb illóolaj-tartalmat magéréskor mértük mindegyik állományban $(0,05-0,29 \mathrm{ml} / 100 \mathrm{~g})$. A populációk között ez esetben is szignifikáns különbségeket tapasztaltunk, betakarítási időtől függetlenül. Illóolaj-összetétel szempontjából az eltérő származású állományok között nem találtunk jelentős különbségeket. Minden taxon mintájában a geranil-acetát, citrál-a és citrál-b voltak a fő illóolaj összetevők. A geranil-acetát illóolajon belüli részaránya a virágzás folyamán nőtt, a legmagasabb értékeket magéréskor mértük (44,7-53\%), míg a citrál koponensek felhalmozása csökkent a virágzás során.

A vizes és alkoholos kivonatok összfenol-tartalmát és összantioxidáns kapacitását összehasonlítva megállapítottuk, hogy a vizes kivonatok minden esetben szignifikánsan magasabb hatóanyag-tartalommal rendelkeztek. Az összfenol-tartalom 
teljes virágzáskor volt a legmagasabb $(226,5-649,2 \mathrm{mg} / \mathrm{g})$, a legalacsonyabb pedig magéréskor (76,9-139,9 mg/g), és antioxidáns-kapacitás esetén is hasonló tendenciát tapasztaltunk. Teljes virágzás ill. elvirágzás során mértük a legmagasabb antioxidánsaktivitást (150,7-276,6 mg/g), mely magéréskor lecsökkent 93,0-151,4 mg/g-ra. 


\section{NATURLAND evolution}

\section{Ruscsák Erika}

NATURLAND Magyarország Kft., 1106 Budapest, Csillagvirág utca 8.

e-mail: erika.ruscsak@naturland.hu

A NATURLAND Magyarország Kft.-nél mindig is törekedtünk a lakosság minél szélesebb köreit megcélozni termékeinkkel. Ezt mutatják felméréseink is, melyek szerint az egyre fiatalabb korosztály is ismeri, használja készítményeinket. Az elektronikus csatornák, közösségi média mellett személyesen is szerettünk volna közelebb kerülni jelenlegi és meglévő vásárlóinkhoz, így 2017-ben elindítottuk Tour de Naturland programunkat, országjáró körutjainkat. Célunk a hazai gyógynövénykultúra bemutatása, a teafogyasztás megkedveltetése, termékeink megismertetése.

Országos üzletkötői, patikai hálózattal rendelkezünk, termékeinket saját gyógyszer-nagykereskedelmi hálózatunk juttatja el az ország valamennyi gyógyszertárába és drogériájába. A hazai (belföldi) kereskedelem mellett a nemzetközi piac meghódítása is célunk, így az export marketingre is kiemelt figyelmet fordítunk.

A fogyasztói igényeket kielégítve a termékkategóriák széles palettáját kínáljuk, melyek előállítása során kiemelkedő jelentőséget fordítunk a minőségre, folyamatos technológiai- és termékfejlesztésekre, a trendek követésére a tradíciókat is szem előtt tartva.

A jogszabályoknak való megfelelés mellett szigorú minőségirányítási rendszerekkel szabályozzuk gyártási folyamatainkat, mindennapi munkánkat. Az üzemrészek korszerūsítése, vizsgáló laboratóriumunk folyamatos bővítése, új gyártó és kiszerelő berendezések beszerzése, folyamataink egyre szigorúbb szabályozása mind hozzájárulnak az állandó minőség garantálásához.

Előadásunkban ismertetjük cégünk változásának, fejlődésének főbb eseményeit, mérföldköveit, érintve jövőbeni fejlesztési, törekvési céljainkat is. 


\section{Egy Kárpát-medencei drogadatbázis szerkesztésének tanulságai és használatának lehetőségei - Farmakobotanikai térképezés \\ a Kis-Küküllő és Nyárád folyók mentén}

Nagy Zsolt

SAPIENTIA Erdélyi Magyar Tudományegyetem, Marosvásárhelyi Kar, Kertészmérnöki Tanszék, 540485 Târgu-Mureș, O.p. 9., C.p. 4.

e-mail: nagycszsolt@yahoo.com

2016 és 2017 között a Kárpát-medence (fél)spontán flórájában előforduló gyógytaxonok és a gyógyszerkönyvek (román, magyar és európai), nemzetközi hivatalos drogmonográfiák (Európai Gyógyszerügynökség monográfiái, European Scientific Cooperative on Phytotherapy és Egészségügyi Világszervezet monográfiák), drogszabványok (román, magyar) és szakkönyvek által szamon tartott növényi eredetű drogok és drogpreparátumok adatbázisának szerkesztését végeztem három (román, magyar és angol) nyelven. Az előadás első részében a szerkesztési alapelvek bemutatása mellett az adatbázis használatának lehetőségeit vázolom, valamint a bevezetett adatokra vonatkozó következtetéseket ismertetem. Az adatbázis által átfogó képet kaphatunk a Kárpát-medencében fellelhető, vadon élő gyógynövényfajok számáról, az általuk szolgáltatott növényi eredetû drogok és drogpreparátumok mennyiségéről. E munka a gyógynövények flóraelem, életforma, természetvédelmi értékkategória, szociális magatartástípus és ökológiai indikátorérték, környezeti igény (hő, víz, talaj, nitrogén, fény, C-érték, sótűrés) szerinti megoszlását is szépen kirajzolja. Lehetőség van továbbá, hogy végre a népi gyógyászat körébe utalandó, kétes etnobotanikai adatokat élesebb határokkal válasszuk el a hivatalos, nyugati orvoslás által is elismert, hatástani vizsgálatokkal értékesnek tartott, hasznosított növények körétől.

Az előadás második felében az adatbázis alkalmazásának lehetőségeit egy esettanulmányon keresztül mutatom be: a ROSCI0297 Natura 2000 területen végzett botanikai felvételezés, farmakobotanikai térképezés és gyógyflóra-potenciál értékelés első évi részeredményeit közlöm. 2016. március 4. és 2017. március 3. között egy 957 ha kiterjedésű mintaterületen 34 napi terepmunkával közel 100 hivatalosan alkalmazott gyógynövényfajt sikerült azonosítani, illetve előfordulásuk pontos helyét térképre vetíteni. Ezzel egyidőben közel félszáz gyógynövényhasonmás dokumentálása, 300 egyéb értékes taxon (például védelem alatt álló növények, ritka orchideafajok stb.), karantén és invazív növények felvétele is megtörtént. Az első év fontos eredménye továbbá a növényzetet és élőhelytípusokat átalakító, befolyásoló, károsító tényezők azonosítása és listába foglalása, elemzése volt. 


\section{György füvesember és a Györgytea története}

Lopes-Szabó Zsuzsanna

Pharmaherb Kft.

e-mail: lopesszabozsuzsa@gyorgytea.hu

A szakmában ismert névvé vált "Gyuri bácsi” történetét nem ismeri mindenki. Leghitelesebb forrásokból, tévhitek és szóbeszédek nélkül kívánom bemutatni azt az embert, aki olyan sokat tett az elmúlt évtizedekben a számára oly kedves gyógynövények népszerűsítése érdekében.

Egy olyan ember történetét ismerhetik meg, aki valóban a kis kosárral kezdte, az erdőből vitte őt a hite és tántoríthatatlan meggyőződése az ismertség felé.

A hagyományos gyógyászat egyik ismert képviselője, szószólója. 30 éve azon munkálkodik, hogy továbbadja azt a tudást és hitet, melyet ő érez a népi gyógyítás, azon belül a gyógynövények iránt. Ő az az ember, aki jókor volt jó helyen: épp elindult a „természethez vissza” mozgalom, felébredt a kiegészítő gyógymódok iránti igény. Részben neki köszönhető, hogy egyre növekszik azok száma, akik bíznak a gyógynövények erejében, akik tudják, hogy kicsi bajra elég egy gyógytea, és hogy a nagyobb betegségeket is könnyebben küzdjük le, ha rásegítünk a terápiára gyógynövényekkel.

Egy család története kapcsán azt a rögös utat szeretném bemutatni, amelyet végigjárt-jártunk a kiskosártól a HACCP-s üzemig, a rendszerváltástól mostanáig, egészen addig, hogy ma itt tartok Önöknek minderről előadást.

Köszönetnyilvánítás: Szabó György füvesembernek és édesapának. 


\section{Etnofarmakobotanikai monográfiák a Homoródok mentéről (Erdély) - Könyvbemutató}

Papp Nóra

PTE GYTK Farmakognóziai Intézet, 7624 Pécs, Rókus u. 2.

e-mail: nora4595@gamma.ttk.pte.hu

Etnobotanikai felméréseinket Erdélyben több mint 30 településen végezzük 2007 óta. A székelyföldi Kis- és Nagy-Homoród mente lakossága számos helyi gyógymódot ismer, elsősorban gyógynövények alkalmazásával. Az előadás a térség két településén, Homoródkarácsonyfalván (HK) és Lövétén (L) végzett több éves kutatás monográfiáit mutatja be (HK: 2011-2015/pp 1-100, L: 2008-2018/pp 1-364).

A kötetek felölelik a településeken említésre került gyógynövényfajok (HK: 177 faj, L: 245 faj) termőhelyi jellemzőit, gyűjtését, készítményeit és helyi alkalmazását színes fényképfelvételekkel, valamint az adatközlők értékes, szó szerinti idézeteivel. A növényi részek mellett állati és számos egyéb anyagot ismertető gyógymód is említésre kerül. A kötetek további fejezeteiben a települések rövid bemutatása (szerkezet, foglalkoztatottság, szociális környezet, szokások, hagyományok, ünnepkörök), az adatgyűjtés módszertana, népi gyógymódokhoz kapcsolódó tájszótár, adatközlők felsorolása, térképek, valamint a növénynevek tudományos és helyi mutatója olvasható.

Az előadás rövid áttekintést ad továbbá a népi orvoslás kutatásának jelenlegi helyzetéről és szükségességéről, kiemelve az európai/erdélyi lehetőségeket és a témakörhöz kapcsolódó feladatokat.

Köszönetnyilvánítás: A kötetek a KA-2017-27 (2017-2018) ÁOK-Kutatási Alapprogram és a PD 108534 Országos Tudományos Kutatási Alapprogram (2013-2017) támogatásával készültek. 


\section{Ellenségből barát - vagy jogos-e a xenofóbia?}

„That would make good of bad, and friends of foes!" (Shakespeare: Macbeth)

\section{László-Bencsik Ábel*, Szatmáry Miklós}

Fitoherb Kft., 1066 Budapest, Teréz krt. 40.

*e-mail: laszlobencsik@fitoherb.hu

Az inváziós növényfajok (Balogh Lajos találó magyarításával: özönnövények) ma egyértelmúen az ellenségeink, noha e nem kívánatos jövevények hasznossá tételének szándéka többször és több szinten is megfogalmazódott. Hatályos gyógyszerkönyvünk is megjelöl invazívként ismert drogforrást (pl. aranyvessző).

Vajon érdemes-e folytatni a sort? Addig a lépésig mindenképpen, hogy legalább a bennük leír hatóanyagok potenciális gyógyászati lehetőségeit számon tartsuk. Ebben a vonatkozásban néhány példát említek:

- a japán keserüfú és hibridje (Fallopia japonica, F. $x$ bohemica) stilbénszármazékai,

- a keskenylevelü ezüstfa (Elaeagnus angustifolia) illóolaja, zsírosolaja, flavonoidjai és alkaloidjai,

- a kaukázusi medvetalp (Heracleum mantegazzianum) kumarinjai és illóolaja,

- a gyalogakác (Amorpha fruticosa) rotenoidjai,

- végül az ailanthon a mirigyes bálványfából (Ailanthus altissima).

Az említett hatóanyagok ugyanakkor nem csak gyógyászati szempontból lehetnek érdekesek, de - invazív fajok ökológiai hadviselésének fegyvereiként tekintve - pozitív vagy negatív szerepet játszhatnak a konzervációbiológia szempontjából is (allelopátia vagy természetes peszticidek). 


\section{A kémiai tér bővítése: \\ természetes és félszintetikus ekdiszteroidokkal rezisztens tumorok ellen}

\section{Hunyadi Attila}

Szegedi Tudományegyetem, Farmakognóziai Intézet, 6720 Szeged, Eötvös u. 6.

e-mail: hunyadi.a@pharm.u-szeged.hu

Az ekdiszteroidok az élővilágban széles körben elterjedt, változatos biológiai funkciókat betöltő természetes szteroidok. Ezeket az anyagokat sok növényfaj képes széles szerkezeti változatosságban előállítani, s egyes képviselőik (pl. a 20-hidroxiekdizon) nagy mennyiségben is hozzáférhetőek. Az ekdiszteroidok a B-gyűrün található enonfunkciónak és számos hidroxilcsoportjuknak köszönhetően félszintetikus átalakításoknak is jó kiinduló pontjai.

Kutatócsoportunk fedezte fel a relatíve alacsonyabb polaritású ekdiszteroidszármazékok tumorrezisztenciára kifejtett erős gátló hatását, amelynek köszönhetően ezek az anyagok számos kemoterápiás szer hatását képesek fokozni. Félszintetikus módszerekkel változatos új származékokat állítottunk elő, s ezek in vitro antitumor hatását számos gyógyszerérzékeny és -rezisztens tumor sejtvonalon vizsgáltuk. Több olyan anyagot is sikerült azonosítanunk, amelyek szelektíven képesek az ABCB1 efflux transzportert kifejező, multidrog-rezisztens tumorsejteket kemoterápiás szerekre érzékenyíteni anélkül, hogy a rezisztenciáért felelős transzporter funkcióját gátolnák. Az előadásban beszámolunk a kapcsolódó kutatási program legújabb eredményeiről.

Köszönetnyilvánítás: A munkát az NKFIH kutatási pályázata (K-119770) támogatta. 


\section{A fény hatása a rozmaring illóolajtermelésére}

Böszörményi Andrea ${ }^{1, *}$, Dobi Adrienn², Pávai Melinda², Solymosi Katalin ${ }^{2}$

${ }^{1} \mathrm{SE}$, Farmakognóziai Intézet, 1085, Budapest, Üllői út 26.

${ }^{2}$ ELTE TTK, Biológiai Intézet, Növényszervezettani tanszék, 1117, Budapest, Pázmány P. s. 1/C.

*e-mail: boszormenyi.andrea@pharma.semmelweis-univ.hu

A rozmaring (Rosmarinus officinalis L.) az ajakosak (Lamiaceae) családjába tartozó mediterrán gyógy- és fúszernövény, melynek levelét és virágát a gyógyászat is használja. A növény leveleiből és virágos hajtásaiból vízgőzdesztillálással nyert rozmaringolajat (Rosmarini aetheroleum) főként külsőleg használják, többek között mozgásszervi megbetegedések tüneteinek enyhítésére, a vérkeringés helyi fokozására. A fajra jellemző illóolaj a növény bőrszövetén található Lamiaceae típusú mirigypikkelyekben, illetve fejes mirigyszőrökben termelődik, főként monoterpén, kisebb részben szeszkviterpén komponensek alkotják, melyek közül hatástani szempontból az $\alpha$-pinén, a cineol, a kámfor és a bornil-acetát a legfontosabbak. Annak ellenére, hogy az emberiség bizonyítottan több mint 2500 éve ismeri és használja is ezt a fajt, a mirigyszőrök ultrastruktúrájáról és múködéséről máig kevés információval rendelkezünk. Ez annál is meglepőbb, mivel a színtesteknek fontos szerepe van a terpenoid-bioszintézisben is, ezáltal befolyásolják az illóolaj-összetétel alakulását, ami meghatározó a várható terápiás hatás szempontjából.

Munkánk során megvizsgáltuk a rozmaring mirigyszőreinek ultrastruktúráját, különös tekintettel a bennük található színtestekre. Egyes kiválasztó sejtekben megfigyeltünk a korábban a családon belül csak a borsmenta (Mentha piperita), illetve a kínai bazsalikom (Perilla ocymoides) mirigypikkelyei esetében leírt különleges, köbös membránszerveződést, ami a sötétben hajtatott zárvatermő növények speciális, ún. prolamelláris testjeihez hasonlított. Így felmerült a kérdés, hogy vajon a színtestek szerveződését és múködését, ezáltal a növények illóolaj-termelését befolyásolja-e a fény illetve annak hiánya. Az előadásban az ultrastrukturális adatok mellett ismertetjük a növény sötétben nevelésének nehézségeit. Bemutatjuk a rendkívül alacsony illóolaj tartalmú etiolált hajtások illóolaj-összetételének meghatározására fejlesztett szilárdfázisú mikroextrakciót követő gázkromatográfiás-tömegspektrometriás módszert (SPME-GC/MS), valamint az általunk vizsgált, fiatal, fényen illetve sötétben fejlődő hajtások illóolaj-összetételének eltéréseit a kifejlett növények leveléhez képest, mind a fő komponensek, mind ezek arányai tekintetében.

Köszönetnyilvánítás: Ezt a kutatást az Emberi Erőforrások Minisztériuma támogatta az ÚNKP-17-4-III-ELTE128 projekt keretében (S.K.). 


\section{Az Európai Gyógyszerügynökség Gyógynövény Bizottságának elmúlt 3 évi tevékenysége}

Biróné dr. Sándor Zsuzsanna

Országos Gyógyszerészeti és Élelmezés-egészségügyi Intézet, 1051 Budapest, Zrínyi u. 3.

e-mail: biro-sandor.zsuzsa@ogyei.gov.hu

Legutóbbi beszámolóm óta (Pannonhalma 2015. május 29-30.) az Európai Gyógyszerügynökség Gyógynövény Bizottsága (HMPC) töretlenül folytatja a növényi gyógyszerek engedélyezését elősegítő munkáját.

Az elmúlt 3 évben 53 új monográfia született, így már 189 kész monográfiá segíti a gyártókat a leendő termékek hatóanyagkiválasztásban. Beindult a meglévők felújítása is, hogy naprakészebb információ álljon rendelkezésre.

Kiváló minőség biztosítása érdekében, a gyártók munkáját segítendő, a növényi gyógyszerek minőségi ellenőrzésével kapcsolatosan újabb kérdések kerültek megválaszolásra a "Q\&A” dokumentumban. A HMPC továbbra is őrködik e termékek biztonságossága felett. Több veszélyt jelentő komponensre dolgozott ki biztonságos határértéket (telítetlen pirrolizidinalkaloidok, mentofurán, pulegon, ösztragol).

Bár nagyon lassan, de növekszik Európában a növényi gyógyszerek száma. 2016. év végéig 1719 hagyományos növényi gyógyszert és 859 növényi gyógyszert (WEU) regisztráltak, sőt a kölcsönös elismerési eljárási folyamat is egyre népszerübb. E számok növelése érdekében a HMPC a jövőben kombinációs készítményeket is kidolgoz, mint ahogy már publikálta a vizelethajtó teakeverék monográfiát. Munkája javítása érdekében rendszeresen szervez az érdekelt szervezetek számára nyílt napot, hogy felmérhesse az igényeket, meghallgassa a kritikákat. 


\title{
Lómenta (Mentha longifolia (L.) L) mint lehetséges antioxidáns-forrás felmérése észak-magyarországi mintákon
}

\author{
Patonay Katalin $^{1, *}$, Szabó-Hudák Orsolya ${ }^{1}$, Szalontai Helga ${ }^{1}$, Pénzesné Kónya Erika, ${ }^{2}$ \\ Zámboriné Németh Éva \\ ${ }^{1}$ Eszterházy Károly Egyetem Élelmiszertudományi és Borászati Tudásközpont, H-3300 Eger, Leányka u. 6G \\ ${ }^{2}$ Eszterházy Károly Egyetem Növénytani és Növényélettani Tanszék, H-3300 Eger, Leányka u. 6D \\ ${ }^{3}$ Szent István Egyetem Gyógy-és Aromanövények Tanszék, H-1118 Budapest, Villányi út 29-43, G ép.
}

*e-mail: patonay.katalin@uni-eszterhazy.hu

A lómenta (Mentha longifolia (L.) L.) vadontermő mentafaj, mely Magyarországon igen elterjedt; ipari felhasználásáról azonban eddig nincs adat. Hosszútávú célunk a növényt - néhány fenoloidokban gazdag populáció kiválasztásával - kísérleti termesztésbe venni; kivonatát az élelmiszeriparban, mint antioxidánst alkalmazni. Munkánk során egyrészt az első tesztelést végeztük el harminchat északmagyarországi lómenta populáció egy-egy mintáján összpolifenol (TPC) tartalmának és antioxidáns kapacitásának jellemzésére, másrészt optimalizálni kívántuk a kivonási módszert. A begyűjtött herbaminták kivonásához oldószerként metanolt (MeOH) ill. 7:3 arányú etanol-víz elegyet (WA) használtunk és mindkettővel mind háromfokozatú Soxhlet-, mind pedig háromfokozatú ultrahangos (UH) extrakciót végeztünk. A TPC meghatározása Folin-Ciocalteu módszerrel, az antioxidáns aktivitás jellemzése pedig a DPPH [1] és FRAP [2] mérés alapján történt.

Megállapítottuk, hogy a TPC alapján a WA hatékonyabb extrahálószere e növénynek, mint a széles körben alkalmazott $\mathrm{MeOH}$. MeOH Soxhlet kivonatból számítva a medián $33243 \mathrm{mg}$ GAE/kg drog, míg a két WA kivonat nem különbözik jelentősen (Soxhlet: 52153; UH: $50651 \mathrm{mg}$ GAE/kg drog) A legtöbb kivonat erős gyökbefogó, de a $B H T$ kontroll aktivitását $\left(E C_{50}=87,36 \mathrm{mg} / \mathrm{l}\right)$ egyik sem éri el. A minták 70\%-ánál a WA UH adta a legerősebb, és a MeOH Soxhlet a leggyengébb gyökbefogó képességet: EC50-re mediánjuk rendre 355,3 és 588,5 mg/l. Mintáink FRAP módszerrel mérhető redukálóképessége középerős; a legmagasabb, 12453 mg AAE/kg drog (kontroll BHT: $12169 \mathrm{mg} / \mathrm{kg}$ ). A minták 58\%-ánál itt is a WA UH módszer volt leghatékonyabb, és a MeOH Soxhlet a leggyengébb: a minták FRAP-értékeinek mediánja e kivonatokból számítva, rendre 8952, ill. 6118 mg AAE/kg drog.

E faj hazai populációiból ez az első analitikai vizsgálat, egyben az antioxidáns aktivitás első olyan felmérése, amelyet közép-európai populációk mintáiból, nagy mintaszámmal végeztek. 
[1] Damien Dorman HJ, Koşar M, Kahlos K, Holm Y, Hiltunen R (2003) J Agric Food Chem. 51:4563-4569. alapján kisebb módosításokkal

[2] Benzie, IFF., Strain, JJ. (1996): Analytical Biochemistry, 239: 70-76. alapján kisebb módosításokkal

Köszönetnyilvánítás: A szerzők köszönetüket fejezik ki EFOP-3.6.1-16-2016-00001 Kutatási kapacitások és szolgáltatások komplex fejlesztése az Eszterházy Károly Egyetemen pályázatnak. 


\section{GLOBE Program Association: Kollaboratív és innovatív tudásplatform a természetes hatóanyagok $\mathrm{K}+\mathrm{F}$ támogatásához}

Polgár Tímea*, Lapusnyik Nóra, Horváth Péter

Envision Biotechnology Kft, www.envisionbiotechnology.com

*e-mail: timea.polgar@envisionbiotechnology.com

Az Egészségügyi Világszervezet becslése szerint Földünkön a betegek jelentős részét, legalább $80 \%$-át természetes szerekkel kezelik. A fejlett ipari országokban használatos gyógyszereknek jelentős része, hozzávetőleg 40\%-a származik természetes forrásokból, ez az arány még magasabb, ha a természetes eredetű származékokat is figyelembe vesszük.

A természetes molekulákon alapuló gyógyszerkutatás számos kihívása ellenére eredményesen járulhat hozzá a gyógyszerinnováció fellendüléséhez. A természetes molekulák a gyógyszerkutatási programok számára új kémiai szerkezeteket szolgáltathatnak, ezen felül a természetes gyógymódokban kódolt tudás hozzájárulhat releváns gyógyszercélpontok felfedezéséhez is.

Napjainkban a komplex megbetegedések és a gyógyszerkészítményekkel szemben támasztott magas követelmények kihívás elé állítják a gyógyszeripart. Az „egy target-egy betegség" koncepció a komplex megbetegedések kezelésére szolgáló gyógyszerek fejlesztésére számos nehézséggel küzd. Erre a célra több hatóanyagot tartalmazó, komplex készítmények lehetnek alkalmasak, amelyek a jelátviteli útvonalakkal számos ponton kölcsönhatnak. Ennek modellezéséhez, megértéséhez és a megfelelő komplex készítmények kifejlesztéséhez a tradicionális gyógymódokban rejlő tudás nyújthat segítséget.

A GLOBE Program Association a természetes molekulákra épülő kutatás támogatására és azok ipari alkalmazásainak segítésére alakult nonprofit szervezet. $\mathrm{A}$ GLOBE program egy olyan üzleti és tudományos piactér, ahol a terület megfelelő kutatóit a szervezet aktívan segíti üzleti és tudományos projektek és együttmúködések kialakításában. A program célul tűzi ki az akadémiai kutatási eredmények ipari fejlesztésekben történő alkalmazását, a fejlődő országokból származó tudás nyomon követését és az abból származó haszon igazságos elosztását. A program keretein belül a területre specifikus tudományos informatikai eszközök és területre specifikus tudásanyag kerül kifejlesztésre, amelyekből a tagok egyenlően részesülnek. 


A XV. MAGYAR GYÓGYNÖVÉNY KONFERENCIA TÁMOGATÓI

Ezüstfokozatú támogatók:

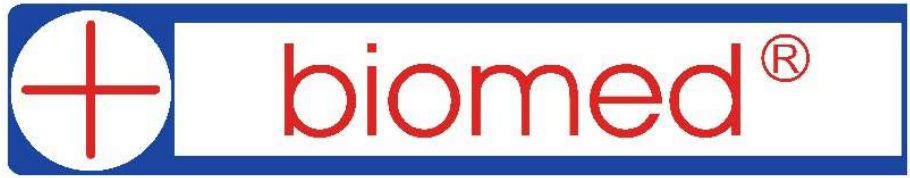

Otthon a természetben ${ }^{\circledR}$

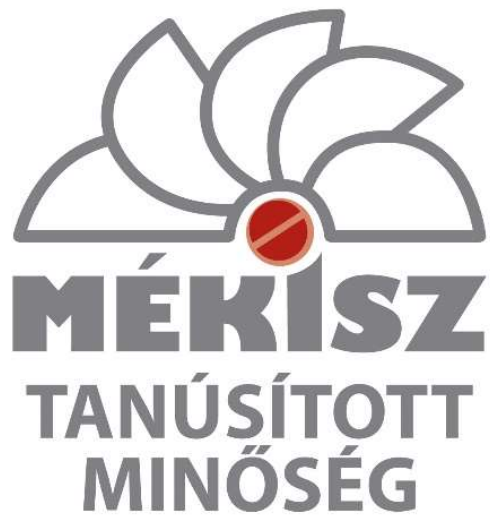

Gyógynövénylap.hu 
Lavandula angustifolia, az év gyógynövénye 2017-ben www.evgyogynovenye.hu

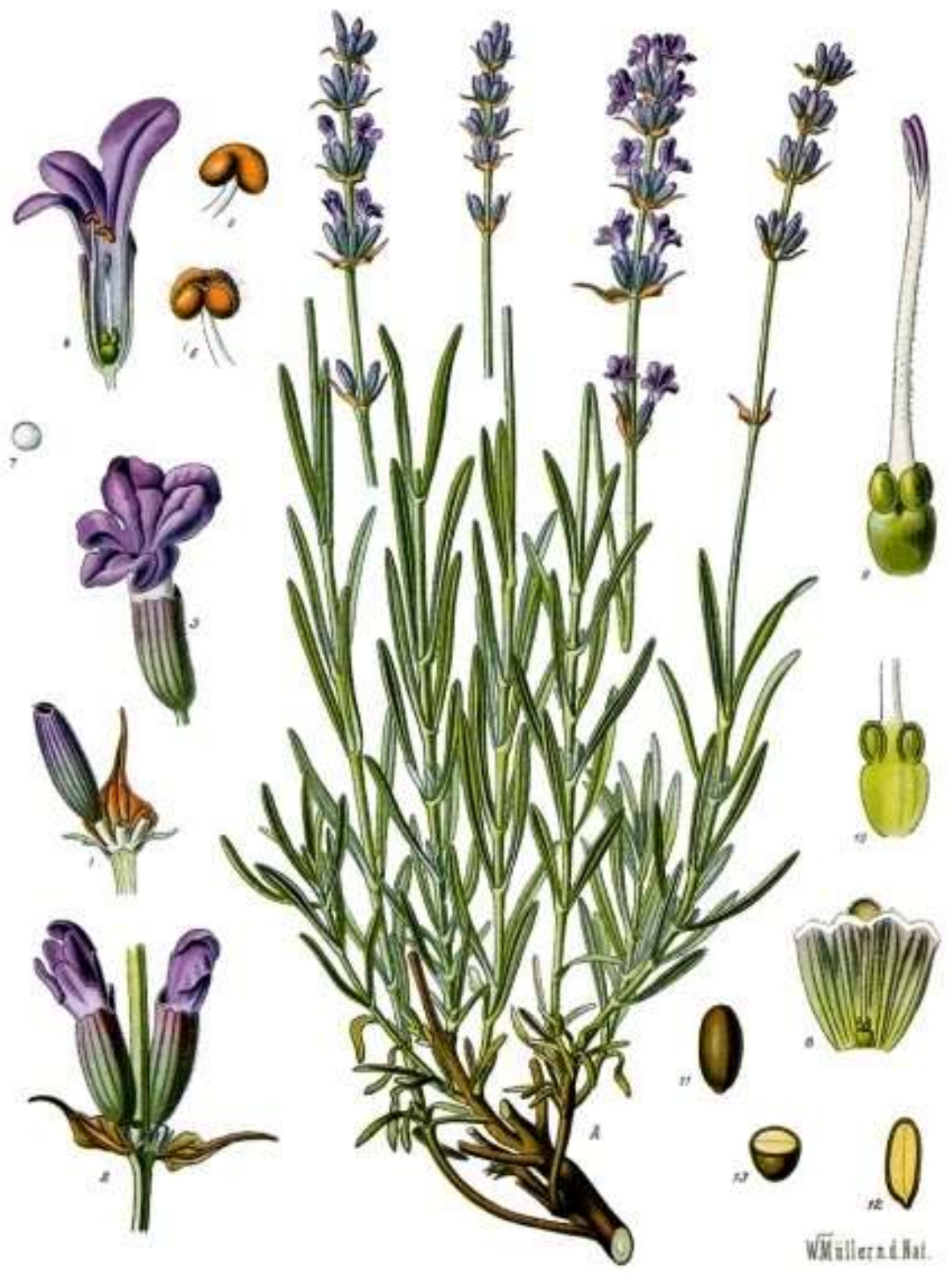

